\title{
コンクリート構造物の電気化学的防食工法
}

\author{
川 俣 孝 治* \\ *住友大阪セメント株式会社
}

\section{Electrochemical Corrosion Control Method for Concrete Structure}

Koji Kawamata*

* Construction Materials Group, Sumitomo Osaka Cement Co., Ltd

\begin{abstract}
This paper explains the electrochemical corrosion control method. This method is an improvement technology for durability of concrete structure, and attracts attention in recent years. The electrochemical corrosion control method is classified into 4 methods, such as cathodic protection method, desalination method, re-alkalization method and electrodeposition method. This paper also shows the principle of these methods, the sphere of applications and construction illustrations.
\end{abstract}

Key words : electrochemical corrosion control method, cathodic protection method, desalination method, realkalisation method, electrodeposition method.

1.はじめに

コンクリート構造物は, 道路, 鉄道, 空港などを構成 するものとして, 我々の身近な存在であり, また重要な 社会資本である.これらコンクリート構造物のほとんど は, 1960 年代から 90 年代初めまでのわずか 30 年間に建 設されたものである. 元来, コンクリート構造物は耐久 性に優れ，メンテナンスフリーなものと言われてきたが, 1980 年代には早期劣化が社会問題となり, 維持管理の重 要性が注目されてきている.この膨大な量の社会資本で あるコンクリート構造物を後世に引き継ぐことが我々， 土木技術者の重要な責務である.

コンクリート構造物の耐久性低下の主な原因として, 中性化, 塩害, 凍害, 化学的侵食, アルカリ骨材反応, 疲労などがある。このうち, 鉄筋やプレストレストコン クリート構造物に用いる鋼材 (PC 鋼材) が腐食する塩害 は,コンクリート構造物の骨の癌とも比喻される重大な 劣化である. 今回は, この塩害対策として近年注目され る電気化学的防食工法を紹介する.

\section{2. 電気化学的防食工法}

コンクリート構造物の塩害対策として用いられる工法 例と, その期待する効果をとりまとめて表 1 に示す1). これまでの塩害対策は, 腐食因子である塩化物イオン, 酸素, 水などを物理的に低減, 除去する工法が用いられ てきた，例えば，エポキシ樹脂などでコンクリート表面 を塗装し，塩化物イオンなどの腐食 因子の供給量を低減する表面処理工 法や，既にコンクリートに含まれる 塩化物イオンを除去するために、コ ンクリートをはつり取り修復する断 面修復工法などである1).

\footnotetext{
* 个102-0085 東京都千代田区六番町 6-28 (628 Rokubancho, Chiyoda-ku, Tokyo, 1020085 Japan)
}

一方, 電気化学的防食工法とは, コンクリート内部に ある鉄筋や PC 鋼材などに外部に設置した陽極から直流 電流を流すことにより，電気化学的反応を利用して，鋼 材腐食に関わるコンクリート構造物の劣化を防止する方 法である。電気化学的防食工法には, 電気防食工法, 脱 塩工法, 再アルカリ化工法, 電着工法があり, これら工 法の特徵を表 2 に示す，電気防食は，コンクリート中の 鉄筋などの鋼材を陰極として防食電流を供給することに より，腐食反応を抑制する方法である，脱塩工法や再ア ルカリ化工法, 電着工法は, 電気防食に比べ数十倍以上 大きな電流を数週間から数力月供給することにより，そ れぞれ次に示すような効果を期待するものである．脱塩 工法では塩化物イオン濃度の低減, 再アルカリ化工法で は中性化したコンクリートの $\mathrm{pH}$ 值の回復, 電着工法で はコンクリート表層部のち密化により, 鋼材腐食の発生 と進行を防止する.これら電気化学的防食工法について, 以下に解説する。

\section{1 電気防食工法2)}

電気防食工法は，継続的な通電を行うことによってコ ンクリート中の鋼材の腐食反応を電気化学的に制御し, 鋼材腐食による劣化の進行を抑制することで，コンクリ 一ト構造物の耐久性を向上させることを目的とした工法 である。

電気防食工法の概念図を図 1 に示す。通電方式には外 部電源方式と流電陽極方式があるが，コンクリートの内 部環境に応じて通電量の調整が可能である外部電源方式 が一般的である．陽極システムは，その形状により，面

表 1 補修・補強に期待する効果と工法

\begin{tabular}{|c|c|}
\hline 期待する効果 & 工法例 \\
\hline 鋼材の贋食因子の供給量を低減 & 表面処理 \\
\hline 鋼材の腐食因子の除去 & 断面修復、電気化学的脱塩 \\
\hline 鋼材の腐食進行を抑制 & 表面処理、電気防食、断面修復、防錆処理 \\
\hline 耐荷力 & FRP 接着、断面修復、外ケーブル、巻立て、増厚 \\
\hline
\end{tabular}


表 2 電気化学的防食工法の主な特徴

\begin{tabular}{|c|c|c|c|c|}
\hline & 電気防食工法 & 脱塩工法 & 再アルカリ化工法 & 電着工法 \\
\hline 通電期間 & 防食期間中継続 & 約 8 週間 & 約 1 2 週間 & 約6ヶ月間 \\
\hline 電流密度 & $0.001 \sim 0.03 \mathrm{~A} / \mathrm{m}^{2}$ & $1 \mathrm{~A} / \mathrm{m}^{2}$ & $1 \mathrm{~A} / \mathrm{m}^{2}$ & $0.5 \sim 1 \mathrm{~A} / \mathrm{m}^{2}$ \\
\hline 通電電圧 & $1 \sim 5 \mathrm{~V}$ & $5 \sim 50 \mathrm{~V}$ & $5 \sim 50 \mathrm{~V}$ & $10 \sim 30 \mathrm{~V}$ \\
\hline 電解液 & - & $\mathrm{Ca}(\mathrm{OH})_{2}$ 水溶液等 & $\mathrm{Na}_{2} \mathrm{CO}_{3}$ 水溶液等 & 海水 \\
\hline 効果確認の方法 & $\begin{array}{l}\text { 鋼材電位または } \\
\text { 鋼材電位変化量の測定 }\end{array}$ & $\begin{array}{l}\text { コシクリートの } \\
\text { 塩化物イオン量の測定 }\end{array}$ & $\begin{array}{l}\text { コンクリートの } \\
\text { 中性化深さの測定 }\end{array}$ & 透水係数の測定 \\
\hline 効果確認の頻度 & 数回/年 & 通電終了後 & 通電終了後 & 通電終了後 \\
\hline
\end{tabular}



図 1 電気防食工法の概念図

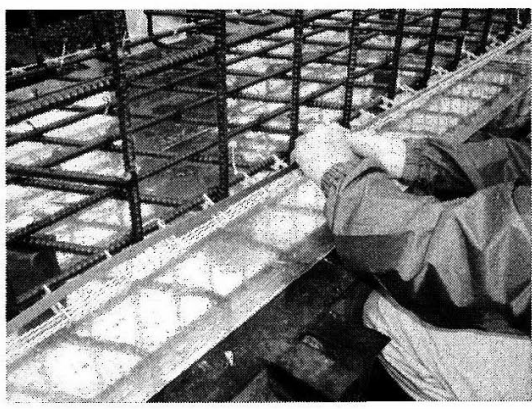

図 2 新設での適用事例（チタンリボンメッシュ方式）
状陽極方式，線状陽極方式，点状陽極方式に区別されて いる. 面状陽極は防食電流の均一性に優れるのに対して, 線状陽極や点状陽極では電流分布を考慮した陽極配置の 検討が重要となる. 各種電気防食システムの例を表 3 に 示す．陽極材の材質はチタンを基材としたものが主であ り，その他のものとしてカーボンを導電材とした塗料や モルタルなどを用いた方式が提案されている.

防食電流は, 鋼材の腐食程度や鋼材量, コンタリート 内部の腐食環境により異なるが，コンクリート表面樍当 りで $0.001 \sim 0.03 \mathrm{~A} / \mathrm{m}^{2}$ 程度が一般的である. 通電制御方 式としては，定電流通電方式または定電圧通電方式が採 用されている．防食電流密度は，100 $\mathrm{mV}$ 以上の分極量ま たは復極量を满足する值とし，コンクリートの電圧降下 による誤差を除いた電位 (インスタントオフ電位)を基準 として評価する。防食電位による防食基準は日本国内で は採用されていない。これは，コンクリートの内部環境 のばらつきが同じ構造物であっても大きいこと，高抵抗 環境であるコンクリート中での鋼材の電位測定は電压降

表 3 各電気防食システムの例

\begin{tabular}{|c|c|c|}
\hline $\begin{array}{l}\text { 電源分式に } \\
\text { よる分類 }\end{array}$ & $\begin{array}{l}\text { 陽極材に } \\
\text { よる分類 }\end{array}$ & 電気防食方式 \\
\hline \multirow{9}{*}{ 外部電源 } & \multirow{6}{*}{ 面状陽極 } & チタンメッシュ陽極方式 \\
\hline & & パネル陽極方式 \\
\hline & & 導電性塗料方式 \\
\hline & & チタン溶射方式 \\
\hline & & チタン覀鉛溶射方式 \\
\hline & & 導電性モルタル方式 \\
\hline & \multirow{2}{*}{ 線状陽極 } & チタンリホンンメッシュ方式 \\
\hline & & チタングリッド方式 \\
\hline & 点状陽極 & チタンロッド方式 \\
\hline \multirow{2}{*}{ 流電陽極 } & \multirow{2}{*}{ 面状陽極 } & 亜鉛シート方式 \\
\hline & & 亜鉛アルミ擬合金溶射方式 \\
\hline
\end{tabular}

下が生じることなどが主な理由である．したがって，定 電位制御による通電方式も国内に拈いては採用されてい ない.

電気防食工法の適用される環境は, 主に大気中部であ る、干満常部や水中部への適用も可能であるが，それぞ れの環境ではコンタリートの抵抗率が異なるため，防食 回路を環境ごとに独立させる設計上の考慮が必要とな る。なお，陽極システムの一部には，水中での付久性に 劣るものもあるので選定に留意しなければならない.プ レストレストコンタリート構造 $(\mathrm{PC})$ ，鉄筋コンクリー 卜構造 $(\mathrm{RC})$ などのいずれの構造形式にも適用可能であ る.ただし， $\mathrm{PC}$ 構造物の場合には $\mathrm{PC}$ 鋼材の水素脆化か らの安全性確保のため, $\mathrm{PC}$ 鋼材の電位を飽和硫酸銅電 極 (CSE) 基準でー $1000 \mathrm{mV}$ より貴な電位に設定しなけれ ばならない. また, 本工法は構造物の劣化レベルに関係 なく適用することが可能である，ただし，劣化レベルに 応じた補修・補強工法との組合せが必要な場合もある。 最近では，過酷な塩害環境において予防保全対策として， 新設時に電気防食を適用する事例もある.（図 2 参照）

防食回路の設計の詳細は陽極システムごとに異なる. 防食回路の規模は, 1 回路を最大で $500 \mathrm{~m}^{2}$ 以下とする場 合が多い。これは，電位分布の均一性を確保するために は 1 回路当りの面積を小さくした方が良いものの，小さ すぎると施工性や経済性の観点では劣るためである。し たがって，設計では，これらを考慮した最適な回路面積 の検討が重要となる.

施工は，(1)コンクリートの前処理, (2)モニタリング 機器の設置, (3) 陽極システムの設置, (4) 直流電源装置 の設置，(5)配線配管のフローで実施されている.

(1) コンクリートの前処理 コンクリートの浮き, 剥落部を断面修復する。ま た，陽極設置面にあるアンカーボルトなどは除去す る. 鋼材間の導通確認は防食回路形成に重要であり, 


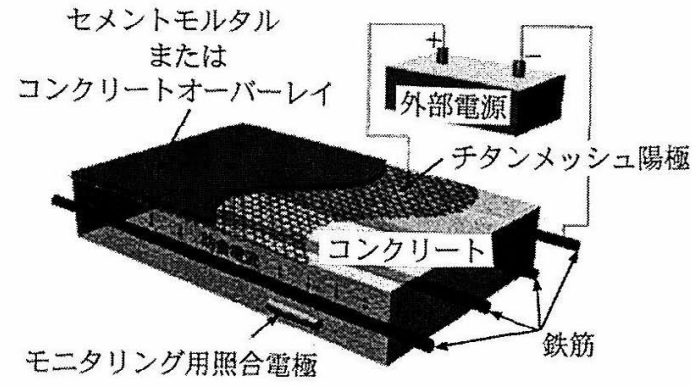

図 3 チタンメッシュ陽極方式の概念図

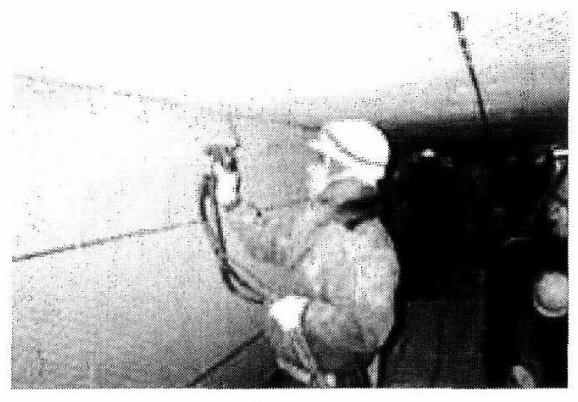

図 4 陽極の設置状況（チタンメッシュ方式）

導通不良箇所は鉄筋や結束線で導通を確保する。

(2) モニタリング機器の設置

照合電極と排流端了を所定の位置に設置する。

(3) 陽極システムの設置

各陽極システムの設置什様に応じて設置する，陽 極設置面にある金属は鋼材との短絡事故となるので 注意する。

(4) 直流電源装置の設置

直流電源装置を所定の位置に設置する。最近では,

ソーラー電池を利用した電源装置や遠隔監視制御機 能が付随したものもある.

(5) 配線配管

陽極システムと直流電源装置の間を配線配管する。

施工事例として, 図 3 および図 4 にチタンメッシュ方 式による施工概念図および陽極の設置状況を示す．チ夕 ンメッシュ方式は, 国内で最も施工実績が多い工法であ る. 施工は，コンクリート表面にチタンメッシュ陽極を 貼りつけ，モルタルでこれをオーバーレイする手順で害 施守る。

\section{2 脱塩工法 ${ }^{2)}$}

脱塩工法は，コンクリート中に存在する塩化物イオン を電気泳動によってコンクリート外部に移動できること に着目し，塩化物イオンを除去もしくは低減することで, 構造物の耐久性を向上させる工法である。

脱塩工法の概念図を図 5 に示す。脱塩工法は, コンク リート表面もしくは表面近傍のコンクリート外部に陽極 材と電解質溶液からなる仮設陽極を設置し，陽極からコ ンクリート巾の鋼材（陰極）へ直流電流を流し，コンク リート中に存在する塩化物イオン（陰イオン）を仮設陽 極側に移動させてコンクリート中から鋼材の腐食因子で ある塩化物イオンを除去もしくは低減させるものであ る.コンクリート中の塩化物イオン濃度を鋼材の腐食発

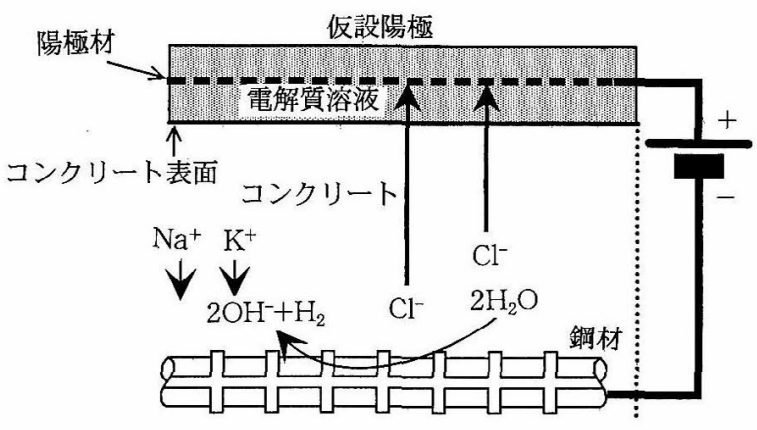

図 5 脱塩工法の概要

生限界塩化物イオン濃度以下とすることで, 腐食環境下 にある鋼材を再不動態化させることを目的とする。

脱塩を行うための電流量は，通常， $1 \mathrm{~A} / \mathrm{m}^{2}$ 程度で, 約 8 週間の通電が一般的である。また，コンクリート中の 塩化物イオンの脱塩処理後に仮設陽極材は撤去する.

脱塩による効果を確認するため, 通電時および通電完 了時にコンクリートサンプルを採取し，塩化物イオン濃 度の測定を行う。

脱塩工法により腐食因子である塩化物イオンの濃度を 低隇させることはできるが，適用後の塩化物イオンの再 浸入や脱掹終了後に残存する塩化物イオンの再拡散等を 考慮した塩化物の再浸透予測などを行う必要がある。飛 来塩化物の影響を受ける塩害環境では，コンクリート表 面にエポキシ樹脂塗装などの表面被覆を併用する場合が 多い.

脱塭工法の適用される環境は, 主に大気中部である. なお，飛沫帯部，干満帯部のいずれの環境でも適用可能 である、 PC, RC などのいずれの構造形式のコンクリー 卜構造物にも適用可能であるが，PC 構造物では PC 鋼材 の水素脆化の危険性があるため, 通電を断続的に行う方 法を採用しなければならない. 塩害とアルカリ骨忉反応 の複合劣化を受けた構造物への適用に対しては, 現時点 では未解明な部分があり, 慎重な対応が必要である. 実 際にコンクリート構造物からコンクリートコアを採取 し，促進膨張試験により残存膨張量を測定し適用を判断 することが賢明である。ささらにリチウムイオンのアル カリ骨材反応の抑制効果を利用し，リチウムイオンの電 解質溶液を用いた脱塩工法などもある.

脱掹工法の施工手順は，陽極材が仮設である点を除き， 電気防食の施工手順之同様である. 陽極材は, チタンメ ッシュを用いる場合が多い。陽極の仮設方式には，(1) フ アイバー方式, (2) パネル方式, (3) ポンディング方式が ある。

(1) ファイバー方式

陽極周辺にセルロースファイバーを吹付ける方式 である、複雑な形状に施工可能であるが, 電解質溶 液の蒸発や漏れが多い.

(2) パネル方式

陽極を樹脂製パネルで覆い，パネル内部に電解質 溶液を充填する方式である．電解質溶液の蒸発や漏 れは少ないが，複雑な形状への施工は難しい

(3) ポンディング方式

コンクリート表面に電解質溶液を貯め，その中に 陽極を仮設する方式である。施工は容易であるが， 


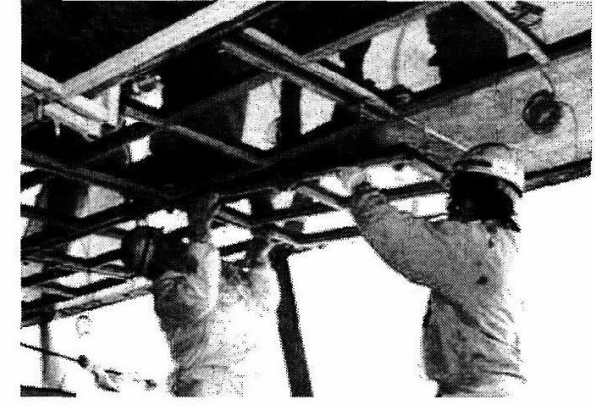

図 6 脱塩工法の施工状況（パネル万式）

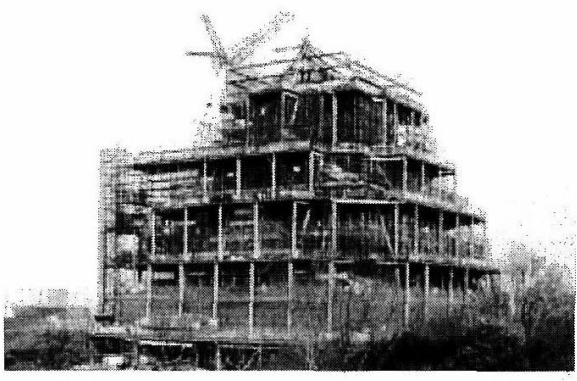

図 8 再アルカリ化工法の施工状況（大阪城）
施工面は水平面 (休面)に限定される。

図 6 にパネル方式による脱塩工法の施工状況を示す. 海砂を使用した場合など内在塩分による塩害を受けたコ ンクリート構造物への適用事例が多い.

\section{3 再アルカリ化工法2}

再アルカリ化工法は, 空気中の二酸化炭素によって中 性化したコンクリート中に電気浸透によって，アルカリ 性溶液を浸透させ，アルカリ性を再付与できることに着 目し，中性化したコンクリートを本来のコンクリートの 有する $\mathrm{pH}$ 值程度にまで回復させ，鋼材を再不動態化す ることで，コンクリート構造物の耐久性を向上させる工 法である。

再アルカリ化工法の概念図を眓 7 に示す。再アルカリ 化工法は，コンクリート表面もしくは表面近傍のコンク リート外部に陽極材とアルカリ性溶液からなる仮設陽極 を設置し，陽極から鋼材（陰極）へ直流電流を流し，コ ンクリート中にアルカリ性溶液を電気浸透させて，コン クリートのアルカリ性を回復させる。再アルカリ化工法 により，コンクリートの $\mathrm{pH}$ 值を回復させ，コンクリー ト中の鋼材を再不動態化させることを日的とする。

再アルカリ化を行う電流量は, 通常, $1 \mathrm{~A} / \mathrm{m}^{2}$ 程度で, 約 1 2 週間の通電が一般的である. また, 脱塩工法と同 様に, 再アルカリ化処理終了後に仮設陽極を撤去する.

再アルカリ化工法の効果は, 適用前後でコアリングで 採取した円柱コアをフェノールフタレイン法により中性 化深さを測定し比較することで確認する。

再アルカリ化工法は, 適用後の構造物の中性化予測な どを行うことや，再アルカリ化処理後に二酸化炭䒺の外 部からの再浸入を防止するために表面処理工法を併用す ることも含めて，適切な維持管理を行うことが重要であ

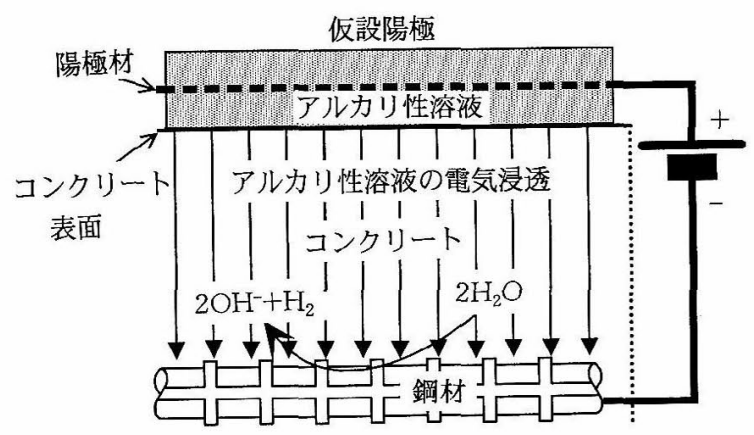

図 7 再アルカリ化工法の概要
る、特に雨水などがかかる部位で電解質溶液の流出が懸 念される場合には，塗装などの表面処理を用いることも 検討する。たたし，再アルカリ化処理後のコンクリート 表面は，含水率， $\mathrm{pH}$ 值がともに高いため，これを考虑 した表面処理工法を選定しなければならない.

再アルカリ化工法は, 鉄筋, 鉄骨, PC 鋼材などを含 むコンクリート構造物に適用可能である。ただし，PC 構造物では, 脱塩工法と同様に, 通電による $\mathrm{PC}$ 鋼材の 水素脆化の危険性がある. そのため, 通電を断続的に行 うなどの対処が必要である. 構造物の劣化の程度に関わ りなく適用可能であるが, 劣化レベルによっては適切な 補修・補强工法との組合せも必要となる。

施工手順は，脱塩工法とほぼ同様である。陽極材はチ タンメッシュ陽極が主に用いられている。電解質溶液は, アルカリ性溶液で電気浸透が行われやすく, 炭酸がスや 水と反応して平衡を維持できるような溶液を使用してい る。一般に, 炭酸ナトリウム, 炭酸カリウム, 炭酸リチ ウムなどが挙げられる.

図 8 に再アルカリ化工法の施工状沉を示す.この写真 は大阪城への適用事例を示したものであるが，このように 中性化した建築コンタリート構造物への適用事例が多い.

\section{4 電 着工 法 ${ }^{2}$}

電着工法は，海水中に存在する電解質イオンを電気泳 動によって，鋼材 (侩極) 側に移動し，ひび割れ部やコ ンクリート表面に無機系物質の電着物を析出することに 着目して，コンクリートに発生したひび割れの閉塞やコ ンクリート表面のち密化を図ることで, 鋼材腐食の進行 を抑制し，構造物の耐久性を向上させる工法である。

図 9 に示すように，仮設陽極材をコンクリート表面か ら離して設置し，コンタリート中の鋼材を陰極として直 流電流を流すことにより，水中の電解質イオンをコンク リート側に引き寄せることができる。コンクリートに発 生しているひび割れ部などの陰極に近い位置から電解質 イオンが電着物として析出し，コンクリート表面全体に 無機系物質の電着物が広がり，コンクリートのち密化を 罒ることを目的とする。

電着工法を行うための電流量は，通常，海水中で 0.5 $\mathrm{A} / \mathrm{m}^{2}$ 程度で, 約 6 力月の通電が一般的である.また, 淡水中や干満帯では, 析出速度が低下するので前述した 以上の通電期間が必要となる。なお，電着工法では，脱 塩工法や再アルカリ化工法と同様に, 電着処理後に, 仮 設陽極材を撤去する.

電着工法は，主に海中部にある栈橋やケーソンなどの 


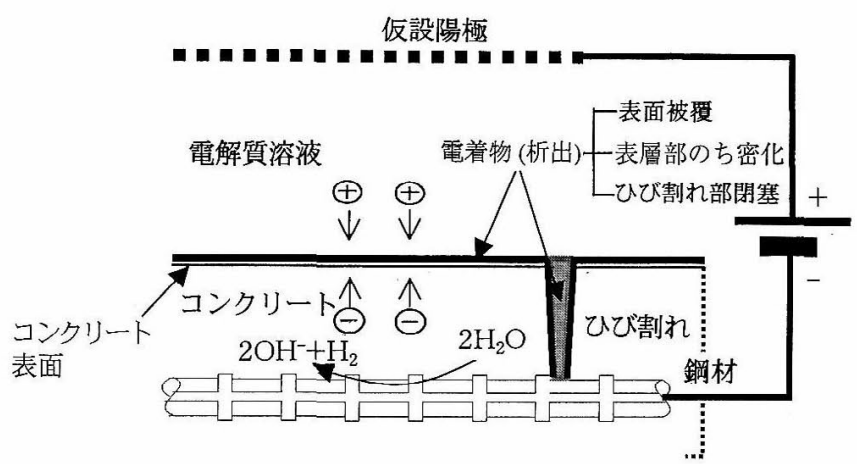

図 9 電着工法の概要



図 10 水中施工方式でのひび割れ閉塞状況

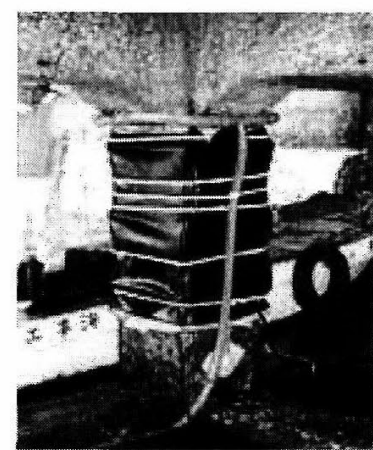

図 11 給水施工方式での電着工法の施工状況

コンクリート構造物に適用される. 陸上や地下のコンク リート構造物に適用された事例もあるが，電解質溶液の 性状，仮設陽極の配置，通電条件などが電着物の析出速 度や電着物の物性に及ぼすので，その影響をあらかじめ 十分に把握しておく必要がある。

仮設陽極の設置方法には，(1) 水中施工方式，(2) 給水 施工方式の 2 種類がある. 図 10 に水中施工方式でのひ び割れ閉塞状況を示す. 四 11に給水施工方式での電着工 法の施工状況を示す。

(1) 水中施工方式

海中部や土中部に陽極を仮設する方式である，施

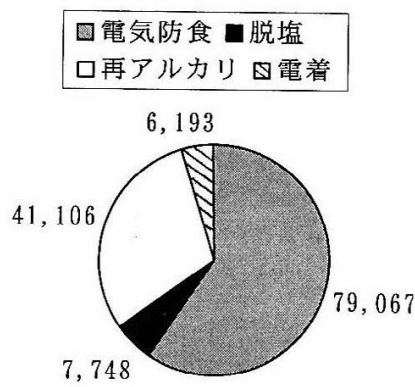

図 12 施工面積の累計 $\left(\mathrm{m}^{2}\right)$

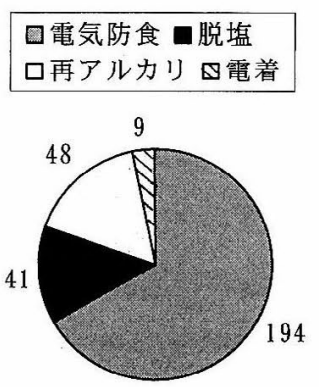

図 13 施工件数の累計
工が簡単であり構造物の形状に左右されないが，仮 設陽極の配置に留意が必要である。

(2) 給水施工方式

大気中部で保水材，陽極材，防水材から構成され る容器を対象コンクリートに仮設する方式である. 部分的な補修に適する。

\section{3. と め}

電気化学的防食工法は，1990 年代初めに日本国内に紹 介され，国内適用環境に適応させるための技術開発や試 験施工が 90 年代半ばにかけて実施された. 実施工レベ ルで本格的に適用され始めたのは，1998 年以降である.

各電気化学的防食工法の 2003 年 3 月末現在での施工 面積および施工件数の累計を図 12 および図 13 に示す. 適用事例は，電気防食执よび再アルカリ化の各工法が大 半を占める。最も実績の多い電気防食で累計約 8 万 $\mathrm{m}^{2}$ である．米国でのコンクリート構造物への電気防食適用 実績は百数十万 $\mathrm{m}^{2}$ を超える.コンクリート構造物の総 量自体の違いもあるが，四方を海に囲まれた島国日本で 塩害が深刻な問題であるのに対して，いまた適用事例が 少ないのが現状である。電気化学的防食工法が土木技術 者に馴染みづらい分野であること, 従来工法に比べて施 エコストが割高であることなどが, 電気化学的防食工法 の普及に障害となっていると思われる。

一方, 構造物の維持管理にアセットマネジメントが導 入されるなど, 構造物の重要性, ライフサイクルから観 たコスト算定が行われ始めた. 電気化学的防食工法は, 更なるコスト削減に向けた技術開発も重要である. それ に加え，ライフサイクルコストでの評価をこれまでの施 工実績をもとに整理することも必要である。

\section{参 考 文 献}

1）土木学会, 2001 年制定コンクリート標準示方書, 維持管 理編

2）土木学会, コンクリートライブラリー 107 , 電気化学的 防食工法設計施工指針（案）(2001).

\section{要旨}

コンクリート構造物の耐久性向上技術として, 近年注目される電気化学的防食工法について解説する. 電 気化学的防食工法には, 電気防食工法, 脱塩工法, 再アルカリ化工法, 電着工法がある. これら工法の原 理，適用範囲，施工事例などについて述べる。

キーワード＼cjkstart電気化学的防食工法, 電気防食法, 脱塩工法, 再アルカリ化工法, 電着工法 